\title{
Expression of the prolactin receptor (tiPRL-R) gene in tilapia Oreochromis niloticus: tissue distribution and cellular localization in osmoregulatory organs
}

\author{
O Sandra ${ }^{1}, \mathbf{P}$ Le Rouzic ${ }^{1}, C_{\text {Cauty }}{ }^{1}$, M Edery $^{2}$ and $\mathbf{P}$ Prunet $^{1}$ \\ ${ }^{1}$ INRA/SCRIBE, Equipe Physiologie de l'Adaptation et du Stress, Campus de Beaulieu, \\ 35042 Rennes Cedex, France \\ ${ }^{2}$ INSERM U344, Endocrinologie Moléculaire, Faculté de Médecine Necker-Enfants Malades, \\ 75015 Paris, France
}

(Requests for offprints should be addressed to P Prunet; Email: prunet@beaulieu.rennes.inra.fr) (O Sandra and P Le Rouzic contributed equally to this work)

\begin{abstract}
The expression of the prolactin receptor (PRL-R) gene has been investigated in various tissues of tilapia (Oreochromis niloticus) reared in fresh or brackish water. Using a cDNA probe spanning the extracellular domain of the tilapia PRL-R and Northern blot analysis, the presence of tilapia PRL-R mRNA has been confirmed in the osmoregulatory organs and has been detected in other tissues, including the skin, the brain, the reproductive organs, and the two major hematopoietic organs (spleen and head kidney), as well as circulating lymphocytes. These findings suggest a conservation of the physiological processes regulated by prolactin throughout the vertebrates, including immunity and central nervous activity. A non-radioactive in situ hybridization procedure has
\end{abstract}

allowed us to detect the expression of the tilapia PRL-R in the branchial chloride cells and the intestinal mucosal layer of fresh water animals, confirming the direct control exerted by prolactin on the water and ionic exchanges in tilapia. In all the tissues examined one unique PRL-R transcript has been detected with a similar size $(3 \cdot 2 \mathrm{~kb})$ whatever the salinity conditions. Thus, the transcriptional expression of the tilapia PRL-R strongly differs from the complex RNA pattern reported for the higher vertebrates PRL-R and provides an additional argument for the existence of a single PRL-R for both prolactin isoforms in this fish species.

Fournal of Molecular Endocrinology (2000) 24, 215-224

\section{INTRODUCTION}

Prolactin (PRL) is a polypeptide hormone, mainly synthesized by the adenohypophysis in vertebrates. More than 300 distinct physiological actions have been identified for this pleiotropic hormone throughout vertebrate species, including effects on water and electrolyte balance, growth and development, metabolism, brain and behavior, reproduction and immunoregulation (Bole-Feysot et al. 1998). In fish, PRL is considered to be the major fresh water adapting hormone, given its ability to regulate the hydromineral balance in the euryhaline teleosts (Hirano 1986). In tilapia, PRL has been shown to be essential for the survival in fresh water of hypophysectomized fish (Dharmamba et al. 1967). Among other osmoregulatory actions, PRL is known to reduce $\mathrm{Na}^{+}$efflux and water permeability at the level of the gill (Dharmamba \& Maetz 1972, Dharmamba et al. 1976, Wendelaar Bonga \& Van der Meij 1981). In addition to its osmoregulatory actions, PRL has been shown to act on other physiological functions, including stimulation of the dermal mucocyte frequency (Flik et al. 1994), pigment dispersion in the tegumentary chromatophores (Kitta et al. 1993), modulation of testosterone production in the testes (Rubin \& Specker 1992), as well as hypercalcemic and corticotrophic effects (Flik et al. 1994) and somatotropic actions (Shepherd et al. 1997). Despite these data, which have shown the involvement of PRL in several aspects of tilapia physiology, scant information is available with regard to tilapia PRL target cells and tissues. 
PRL initiates its actions through binding to a specific cell surface receptor (PRL-R), which has been cloned in various tetrapod species and belongs to the cytokine class-1 receptor superfamily (BoleFeysot et al. 1998). The wide tissue distribution of the PRL-R reported at the RNA as well as the protein level is in agreement with the broad spectrum of PRL functions (Bole-Feysot et al. 1998). Different PRL-R isoforms, which differ primarily by the lengths of their cytoplasmic domains, have been identified in rodents and mammals (Kelly et al. 1991, Anthony et al. 1995, Jabbour et al. 1998). Multiple PRL-R transcripts corresponding to either PRL-R isoform have been described in mammals and are associated to a complex pattern of expression and regulation $(\mathrm{Hu}$ et al. 1998).

In fish, studies investigating the PRL-R have been carried out mainly with both tilapia species Oreochromis niloticus and Oreochromis mossambicus. In these species two PRL forms produced by two different genes have been characterized, tiPRL-I (188 amino acids) and tiPRL-II (177 amino acids), their primary sequences sharing only $69 \%$ identity (Yamaguchi et al. 1988, Rentier-Delrue et al. 1989). Binding studies using recombinant tiPRLs indicate the presence of a single class of high-affinity binding sites for both tiPRLs (tiPRL-R), which always bind tiPRL-I with a higher affinity than tiPRL-II in gill and kidney (Auperin et al. 1994b). Screening of a kidney cDNA library by an expression cloning strategy has enabled us to isolate a tiPRL-R cDNA whose sequence has been determined (Sandra et al. 1995). The overall structure of the protein is similar to that of the long form of the mammalian PRL-R. Upon the transfection of this cDNA in mammalian cells, the translated tiPRL-R exhibits binding properties for tiPRLs close to those previously reported in vivo (Sandra et al. 1995). Moreover, preliminary data have shown the expression of a single $3.2 \mathrm{~kb}$ transcript in both gill and kidney, providing an additional argument in favor of a unique receptor in these osmoregulatory organs. This is clearly different from what has been reported in higher vertebrates. Nevertheless, in mammals, the expression of either PRL-R isoforms is sometimes restricted to a particular physiological status or a specific target tissue (Hu et al. 1998, Jabbour et al. 1998).

This study has been undertaken in order to identify PRL target tissues as well as to locate the cellular distribution of the PRL-R in some organs and to assess the pattern of the PRL-R transcriptional expression in tilapia Oreochromis niloticus. Using Northern blot analysis, we have investigated both tissue distribution and number of RNA transcripts encoding the PRL-R in tilapia under various salinity conditions. Using in situ hybridization, the cellular localization of the tiPRL-R has been examined in two major osmoregulatory organs, the gill and the intestine.

\section{MATERIALS AND METHODS}

\section{Animals}

Adult tilapia (Oreochromis niloticus) were reared in recirculating fresh water or were adapted for 20 days in brackish water (salinity: 20\%o), under constant photoperiod (12 h light:12 h darkness) and temperature $\left(26^{\circ} \mathrm{C}\right)$. The osmoregulatory, hematopoietic and reproductive tissues, as well as the skin, were sampled from animals of both sexes weighing $80-100 \mathrm{~g}$ and undergoing either vitellogenesis or spermatogenesis (early to mid-gametogenesis). Skin was sampled from the abdominal region after the scales had been carefully removed. Brains were collected from males weighing 600-700 g.

\section{Tissue collection and lymphocyte preparation}

Fish were netted individually, rapidly bled by caudal puncture using a heparinized syringe and killed by decapitation. Tissues were immediately dissected out and either snap-frozen in liquid nitrogen for RNA extraction or fixed for in situ hybridization. To isolate tilapia lymphocytes, whole blood was diluted into 4 volumes of RPMI 1640 medium (Gibco BRL-Life Technologies, Cergy-Pontoise, France), layered onto Ficoll-Paque density gradient (d: 1.077, Pharmacia, Uppsala, Sweden) and centrifuged at $500 \mathrm{~g}$, at $20^{\circ} \mathrm{C}$, for $40 \mathrm{~min}$. The lymphocytes recovered from the interface were washed twice in RPMI 1640 (400 g, $10 \mathrm{~min}, 20^{\circ} \mathrm{C}$ ). Cell viability was determined by Trypan Blue exclusion and was always greater than $95 \%$. After centrifugation the cell pellet was immediately frozen and stored at $-80^{\circ} \mathrm{C}$ until use.

\section{Preparation of hybridization probes}

For Northern blot analysis, a $0.9 \mathrm{~kb}$ cDNA fragment was isolated from a pcDNA1 vector by BamHI endonuclease digestion (Sandra et al. 1995) and further purified by agarose gel electrophoresis. This fragment corresponds to the extracellular domain of the tiPRL-R and a part of the 5 non-translated region. In some experiments, a rainbow trout $\beta$-actin cDNA was used (Pakdel et al. 1989) as a control for the integrity and membrane blotting of RNA samples. Both probes were 
labeled by a random-primed DNA labeling kit (Amersham, Les Ulis, France) using $\left[\alpha-{ }^{32} \mathrm{P}\right] \mathrm{dCTP}$ (3000 Ci/mmol; Amersham).

For in situ hybridization, a 720 base pair (bp) fragment encompassing the extracellular domain of the tiPRL-R was generated by polymerase chain reaction with two primers which included one BamHI restriction site each (forward: $5^{\prime}$-CGCGGA TCCCAATGATGACGAAAGTCGGAGAAG-3' and reverse: 5'-CGACCTAGGAGACAGACTTT TCCC-3'). The PCR amplified product was then ligated into the BamHI site of the pcDNA3 vector (Invitrogen, San Diego, CA, USA) and insert orientation was determined by restriction profile. Both antisense and sense RNA probes were synthesized using fluorescein-11-dUTP and the RNA colour kit (RPN 3300, Amersham). Transcription was performed using T7 RNA polymerase with the EcoRI-linearized template for the antisense riboprobe or using SP6 RNA polymerase with the HindIII-linearized template for the sense riboprobe. Probe-labeling efficiency was assessed by UV transillumination and a dot-blot analysis including an aliquot of each labeled RNA probe and serial dilutions of the fluorescein-dUTP ribonucleotide.

\section{Northern-blot analysis}

Total RNA was extracted from various tissues and lymphocytes previously stored at $-80{ }^{\circ} \mathrm{C}$, using the guanidium-isothiocyanate-phenol method (Chomczynski \& Sacchi 1987). Five to fifteen animals were used, according to the abundance of the analyzed tissue. The poly (A)+ RNAs were then enriched by passing total RNA through an oligo-dt cellulose column (Eurobio, Les Ulis, France), according to Aviv \& Leder (1972). RNA yields and purity were estimated by spectrophotometry at 260 and $280 \mathrm{~nm}$. Samples of 5-9 $\mu \mathrm{g}$ of poly (A)+ RNA were size separated by electrophoresis in $1 \%$ agarose-formaldehyde gel and transferred to nylon membranes (Biodyn-Pall; Pall Europe Ltd, Portsmouth, Hants, UK) by capillary blotting, in $20 \times \mathrm{SSC}(1 \times \mathrm{SSC}$ is $150 \mathrm{mmol} / 1$ sodium chloride, $15 \mathrm{mmol} / \mathrm{l}$ sodium citrate $\mathrm{pH}$ 7). Following crosslinking by ultraviolet irradiation, the membranes were prehybridized in a $0.5 \mathrm{~mol} / 1$ phosphate buffer (Church \& Gilbert 1984) at $65{ }^{\circ} \mathrm{C}$ for $4-5 \mathrm{~h}$. High stringency hybridization was carried out at $65^{\circ} \mathrm{C}$ overnight with the ${ }^{32} \mathrm{P}$-labeled probe $\left(1 \times 10^{6}\right.$ c.p.m./ml) diluted in an aliquot of the same buffer. Filters were washed twice in $2 \times \mathrm{SSC}, 0 \cdot 1 \% \mathrm{SDS}$ for $5 \mathrm{~min}$ each at room temperature, then twice in $0 \cdot 2 \times \mathrm{SSC}, 0 \cdot 1 \% \operatorname{SDS}$ for $15 \mathrm{~min}$ each at $65^{\circ} \mathrm{C}$. Lower stringency conditions are characterized by (i) a lower incubating temperature $\left(55^{\circ} \mathrm{C}\right)$ for both

www.endocrinology.org prehybridization and hybridization and (ii) two washes at room temperature for $5 \mathrm{~min}$ each and one at $55^{\circ} \mathrm{C}$ for $10 \mathrm{~min}$ with $2 \times \mathrm{SSC}, 0 \cdot 1 \%$ SDS. Membranes were first hybridized with the labeled tiPRL-R cDNA probe, then stripped and rehybridized with the labeled rainbow trout $\beta$-actin cDNA probe. Autoradiography was performed by exposing the filters to Hyperfilm (Amersham), at $-70{ }^{\circ} \mathrm{C}$ with intensifying screens.

\section{In situ hybridization}

Dissected tilapia tissues were carefully rinsed with sterile cold PBS and fixed in $4 \%$ paraformaldehyde solution in PBS for $3-4 \mathrm{~h}$ at $4{ }^{\circ} \mathrm{C}$. The samples were then dehydrated at $4{ }^{\circ} \mathrm{C}$ through a graded ethanol series, infiltrated with butanol at room temperature and embedded in paraffin. Serial sections of $5 \mu \mathrm{m}$ were cut and mounted on slides precoated with 3-aminopropyltriethoxysilane (TESPA; Sigma, St Quentin Fallavier, France) or on polylysine coated slides (C.M.L., France) for gills. Gill sections were cut parallel to the long axis of the primary lamellae at a right angle to the secondary lamellae. Prior to the hybridization, slides were rehydrated, permeabilized with a proteinase $\mathrm{K}$ solution $(1 \mu \mathrm{g} / \mathrm{ml}$ in $10 \mathrm{mmol} / \mathrm{l}$ Tris, $1 \mathrm{mmol} / \mathrm{l}$ EDTA, pH 8) for $10 \mathrm{~min}$ at $37^{\circ} \mathrm{C}$, washed in $\mathrm{PBS}$, treated with $0 \cdot 1 \mathrm{~mol} / 1$ glycine in $0 \cdot 1 \mathrm{~mol} / 1$ Tris $\mathrm{pH} 7 \cdot 2$, postfixed in $4 \%$ paraformaldehyde, washed in PBS, serially dehydrated in ethanol and then air dried. After treatment, sections were prehybridized for $30 \mathrm{~min}$ at $42{ }^{\circ} \mathrm{C}$ with the hybridization buffer supplied with the RNA color kit to which $500 \mu \mathrm{g} / \mathrm{ml}$ yeast tRNA was added. Either the antisense or the sense fluorescein-labeled riboprobe was diluted in this buffer (100-200 $\mathrm{ng} / \mathrm{ml}$ ) and applied to the sections, overlaid with coverslips and incubated overnight at $42{ }^{\circ} \mathrm{C}$ in a moist chamber. Slides were sequentially washed twice in $2 \times \mathrm{SSC}$ for $10 \mathrm{~min}$ at room temperature, once in $2 \times \mathrm{SSC}$ for $20 \mathrm{~min}$ at $55^{\circ} \mathrm{C}$ and twice in $0 \cdot 2 \times \mathrm{SSC}$ for $20 \mathrm{~min}$ at $55^{\circ} \mathrm{C}$. Finally, sections were incubated in the presence of a sheep anti-fluorescein antibody conjugated to alkaline phosphatase, and expression of the tiPRL-R was visualized by substrate development (Nitro Blue tetrazolium salt, NBT, and 5-bromo-4-chloro-3inodyl phosphate, BCIP) for various durations, according to the recommendations of the manufacturer. In some cases, sections were counterstained with methyl green. Morphology of tissues was also confirmed by hematoxylin-eosin staining on adjacent sections. Absence of endogenous and non-specific reactions was assessed by incubating tissue sections with substrates (NBT and $\mathrm{BCIP}$ ) required for signal visualization and 
either the antisense labeled riboprobe or the anti-fluorescein antibody coupled to alkaline phosphatase.

\section{Immunohistochemistry}

Gill sections were prepared and mounted as described above. In order to reduce the non-specific staining, the sections were treated with $10 \%$ normal pig serum in Sorensen buffer $\left(\mathrm{Na}_{2} \mathrm{HPO}_{4}, 12 \mathrm{H}_{2} \mathrm{O}\right.$ $0.1 \mathrm{~mol} / \mathrm{l}$ adjusted to $\mathrm{pH} 7 \cdot 4$ with $\mathrm{NaH}_{2} \mathrm{PO}_{4}, 2 \mathrm{H}_{2} \mathrm{O}$ $0.1 \mathrm{~mol} / \mathrm{l}$ ) for $20 \mathrm{~min}$ at room temperature. The andogenous peroxidase activity was neutralized by treatment of the sections with a saponin solution $(0 \cdot 1 \%$ in Sorensen buffer $)$ then a $\mathrm{H}_{2} \mathrm{O}_{2}$ solution $(0.3 \%$ in water $)$. The sections were incubated first with the primary antibody (dilution 1:50) overnight at $4{ }^{\circ} \mathrm{C}$, then with an anti-mouse $\operatorname{IgG}$ coupled with peroxidase (dilution $1: 100$ ) for $90 \mathrm{~min}$ at $20^{\circ} \mathrm{C}$ and finally with a sheep anti-peroxidase antibody (dilution 1:600) for $60 \mathrm{~min}$ at $20{ }^{\circ} \mathrm{C}$. The primary antibody developed by Dr D M Fambrough (Department of Biology, Johns Hopkins University, Baltimore, MD, USA) is a mouse monoclonal a5-immunoglobulin $\mathrm{G}(\mathrm{IgG})$ directed against chicken $\mathrm{Na}^{+}, \mathrm{K}^{+}$-ATPase $\alpha$-subunit and was obtained from the Developmental Studies Hybridoma Bank maintained by the University of Iowa, Department of Biological Sciences, Iowa City, USA (NO1-HD-73263 from the National Institute of Child Health and Human Development). Visualization of the immunoreactive sites

FIGURE 1. Northern blot analysis of prolactin receptor (PRL-R) expression in the osmoregulatory tissues and the skin of tilapia. (A) Poly (A) ${ }^{+}$RNAs $(9 \mu \mathrm{g})$ were purified from the gill, the posterior kidney and the intestine collected from animals reared in fresh water $(\mathrm{F})$ or adapted to brackish water for 20 days (B). RNAs were electrophoresed and transferred to a nylon membrane. The membrane was first hybridized with the $\left[\alpha-{ }^{32} \mathrm{P}\right] \mathrm{dC}$ TP-labeled cDNA probe encoding the extracellular domain of the tilapia PRL-R using high stringency conditions (upper panel; exposure time: 5 days), stripped and reprobed with the rainbow trout $\left[\alpha-{ }^{32} \mathrm{P}\right] \mathrm{dCTP}$-labeled $\beta$-actin cDNA probe (lower panel; exposure time: $5 \mathrm{~h}$ ). (B) Poly $(\mathrm{A})^{+}$RNAs $(5 \mu \mathrm{g})$ were purified from the gill, the posterior kidney, the posterior intestine and the skin collected from fresh water-adapted animals. RNA were electrophoresed and transferred to a nylon membrane. The blot hybridization was carried out with the $\left[\alpha-{ }^{32} \mathrm{P}\right] \mathrm{dCTP}$-labeled cDNA probe encoding the extracellular domain of the tilapia PRL-R using low stringency conditions (exposure time: 10 days). The estimated size (bp) of the tilapia PRL-R transcript is indicated on the left and the sizes of the RNA molecular markers are shown on the right. was performed by dipping the slides into the revelation buffer $(50 \mathrm{ml}$ ammonium citrate, $5 \mathrm{mg}$ chloronaphthol in $1 \mathrm{ml}$ methanol, $20 \mathrm{ml} \mathrm{H}_{2} \mathrm{O}_{2}$ ) for $10 \mathrm{~min}$ in the dark. The reaction was stopped in water then the sections were further stained with periodic acid and Schiff's reagent (PAS).

A

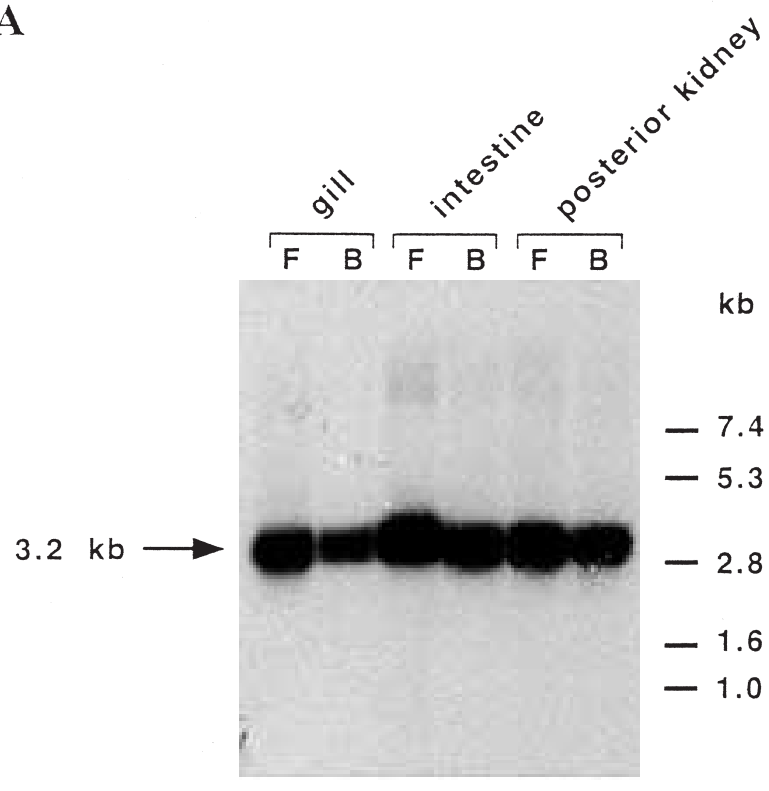

$\beta$-actin
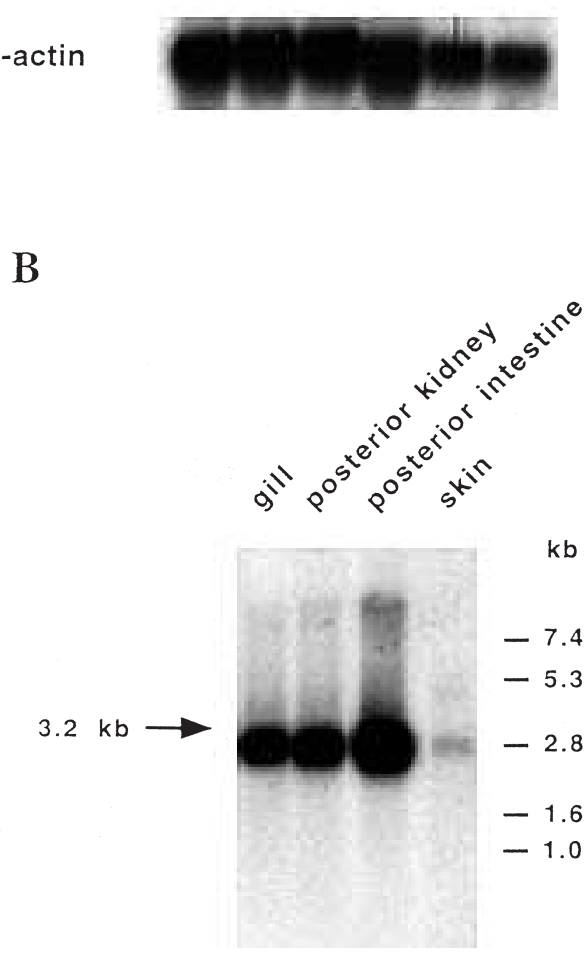

www.endocrinology.org

Downloaded from Bioscientifica.com at 04/26/2023 04:35:14AM via free access 


\section{RESULTS}

To investigate the tissue distribution of the tiPRL-R transcripts in tilapia, Northern blot analysis was carried out with poly (A)+ RNA prepared from a variety of tissues collected from tilapia reared in fresh water $(\mathrm{FW})$ or adapted for 20 days in brackish water (BW). The cDNA probe corresponded to a fragment of the 5 non-coding region and the extracellular domain of the tiPRL-R.

In the osmoregulatory organs including gill, posterior kidney and full-length intestine, a unique $3.2 \mathrm{~kb}$ transcript was easily detected both in FW and in BW (Fig. 1A). In the intestine, our preliminary data have also shown an expression level of this unique transcript higher in the posterior part than in the anterior part (O Sandra, $P$ Le Rouzic, F Rentier-Delrue \& P Prunet, unpublished data). Under less stringent hybridization and washing conditions, no transcript other than this $3 \cdot 2 \mathrm{~kb}$ band was visualized in these tissues or the skin (Fig. 1B). A similar pattern of transcript distribution was observed in the male brain and reproductive organs of both sexes, including testes and ovaries collected from tilapias undergoing gametogenesis (Fig. 2A). Finally, the expression of the tiPRL-R was studied in the two major hematopoietic organs and circulating lymphocytes in adult tilapia. A distinct single $3 \cdot 2 \mathrm{~kb}$ band was

FIGURE 2. Prolactin receptor (PRL-R) expression in the central nervous system, the reproductive organs and the hematopoietic organs of tilapia. (A) Northern blot was performed with $4 \mu \mathrm{g}$ of poly $(\mathrm{A})^{+}$RNA purified from the brain sampled from mature male tilapia and $9 \mu \mathrm{g}$ of poly $(\mathrm{A})^{+}$RNA purified from the testes or the ovaries collected from tilapia undergoing the gametogenesis. Animals were reared in fresh water. The filter was hybridized with the $\left[\alpha-{ }^{32} \mathrm{P}\right] \mathrm{dCTP}$-labeled cDNA probe encoding the extracellular domain of the tilapia PRL-R using high stringency conditions. The exposure time was 12 days for the brain and 20 days for the reproductive tissues, respectively. (B) Northern blot analysis was carried out with poly $(\mathrm{A})^{+}$RNA $(9 \mu \mathrm{g})$ purified from the spleen, the head kidney and the circulating lymphocytes collected from animals reared in fresh water $(\mathrm{F})$ or adapted to brackish water for 20 days (B). The membrane was first hybridized with the $\left[\alpha-{ }^{32} \mathrm{P}\right] \mathrm{dCTP}-\mathrm{Tabeled}$ cDNA probe encoding the extracellular domain of the tilapia PRL-R using high stringency conditions (upper panel; exposure time: 20 days), stripped and reprobed with the rainbow trout $\left[\alpha-{ }^{32} \mathrm{P}\right] \mathrm{dCTP}$-labeled $\beta$-actin cDNA probe (lower panel; exposure time: $5 \mathrm{~h}$ ). The estimated size (bp) of the tilapia PRL-R transcript is indicated on the left and the sizes of the RNA molecular markers are shown on the right.

www.endocrinology.org visible in the anterior kidney (or head kidney) and this signal was also displayed by both spleen and lymphocytes, although with a lower intensity (Fig. 2B). In head kidney and lymphocytes collected from $\mathrm{BW}$-adapted tilapia, the $3 \cdot 2 \mathrm{~kb}$ transcript was still detectable (Fig. 2B).

To determine the cellular localization of the tiPRL-R in gill and the posterior intestine collected from tilapia reared in $\mathrm{FW}$, in situ hybridization was performed using an antisense fluorescein-labeled

A

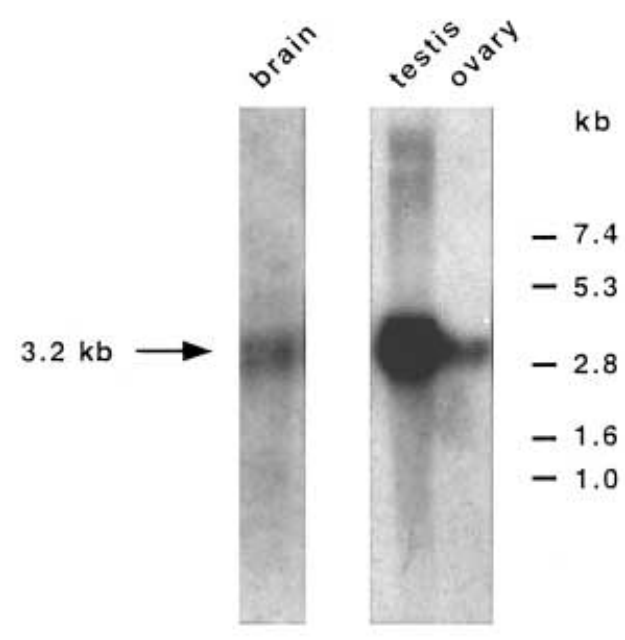

B

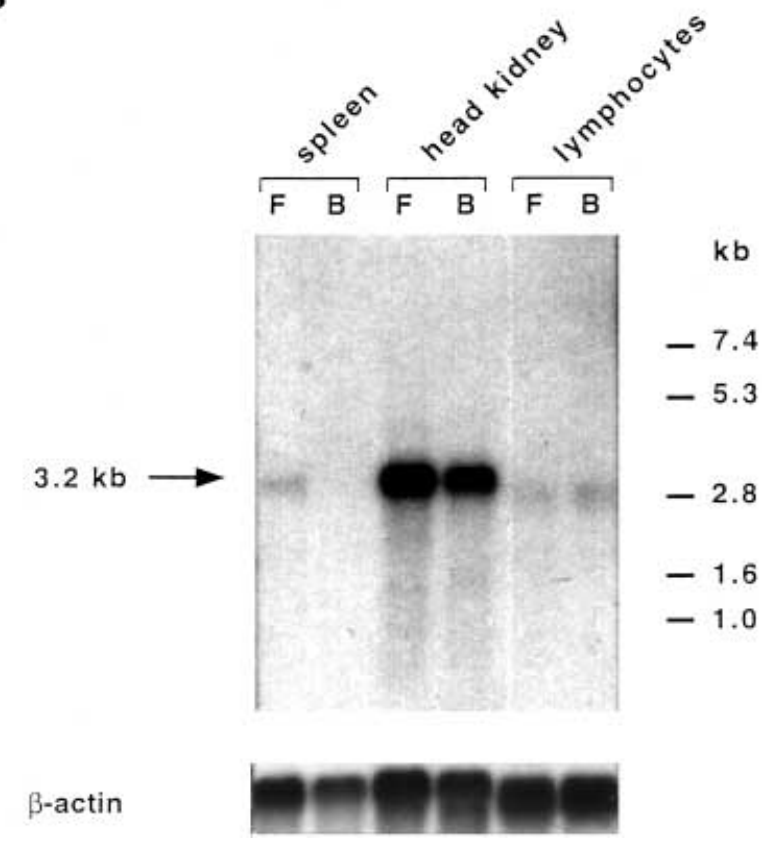

Fournal of Molecular Endocrinology (2000) 24, 215-224 Downloaded from Bioscientifica.com at 04/26/2023 04:35:14AM via free access 

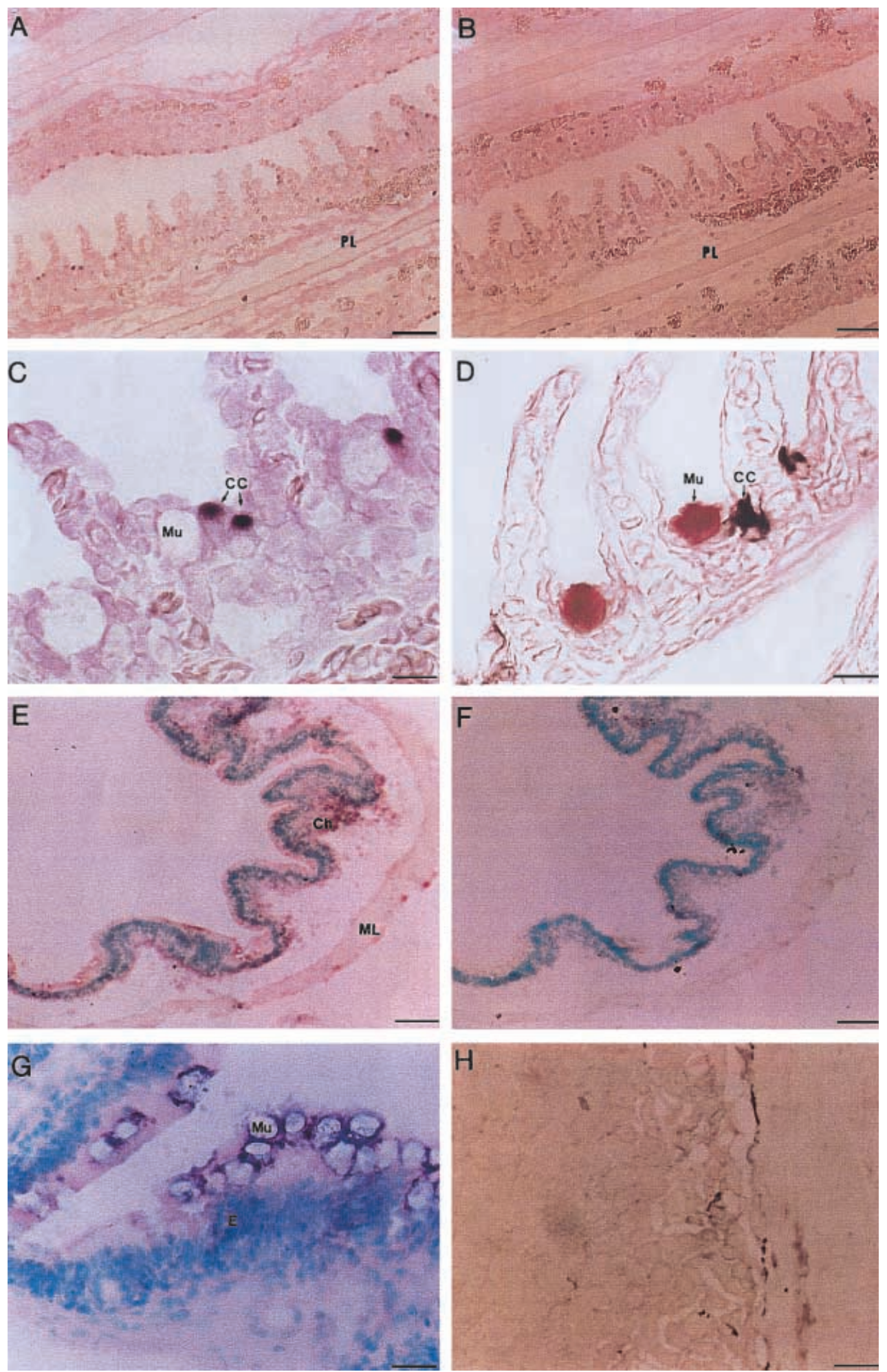
RNA probe spanning the tiPRL-R extracellular domain. As a negative control for these observations, we used adjacent sections incubated with the sense fluorescein-labeled riboprobe (Fig. $3 \mathrm{~B}$ and F). Another internal control for absence of non-specific labeling was the use of muscle slides incubated with either sense or antisense probe (Fig. $3 \mathrm{H}$ ). No signal was revealed, which is consistent with the absence of tiPRL-R gene expression in this tissue as previously shown by Northern blot analysis (Sandra et al. 1995).

In the gill, analysis of sections cut parallel to the long axis of the filament shows the intense expression of the tiPRL-R within cells localized in the interlamellar region of the primary epithelium (Fig. 3A and C). These cells were identified as chloride cells by immunochemistry using an anti- $\mathrm{Na}^{+}, \mathrm{K}^{+}$-ATPase $\alpha$ subunit antibody. This antibody clearly marked similar epithelial cells located on the primary lamellae at the base of the secondary lamellae (Fig. 3D). Mucous cells were also identified using PAS staining, but this procedure clearly labeled different cells from those showing high expression of tiPRL-R gene: mucous cells were larger cells, located in the middle of the primary lamellae and containing visible mucous vesicles. Thus, these results confirm that the expression of tiPRL-R gene was specifically located in chloride cells and that no other branchial cell type including respiratory cells or non-differentiated cells exhibits any specific signal.

In the transverse sections of the posterior part of the intestine, the cells forming the intestine epithelium (enterocytes and mucous cells), as well as chorion cells, exhibit a specific expression of the tiPRL-R mRNA (Fig. 3E and G). The signal is also barely visualized in the muscularis layer (Fig. 3E).

\section{DISCUSSION}

Using a homologous cDNA probe encoding the extracellular domain of the tiPRL-R and Northern blot analysis, the expression of the PRL-R gene has been detected in various tissues of tilapia. Our findings confirm that PRL exerts pleiotropic effects and also demonstrate the implication of this hormone in the regulation of various physiological functions in tilapia. Our Northern blot data show an expression of the tiPRL-R transcript in the gills, the kidney and the intestine, the three major organs involved in teleost osmoregulation. In keeping with the abundant literature illustrating the osmoregulatory effects induced by PRL in these organs (Hirano 1986), this result corroborates those of Prunet \& Auperin (1994) which show a high level of tiPRL-specific binding in these tissues and both illustrate the crucial role of PRL in the regulation of the hydromineral balance. In agreement with this conclusion, a recent study by Shiraishi et al. (1999) analyzed the expression of PRL-R transcripts during early life stages of tilapia O. mossambicus and described changes of transcript levels when embryos were transferred to sea water. Interestingly, recent studies by O Sandra, P Le Rouzic, F RentierDelrue \& P Prunet (unpublished data) also indicated a differential regulation of the tiPRL-R expression in these three osmoregulatory organs in tilapia transferred from fresh to brackish water.

The $3 \cdot 2 \mathrm{~kb}$ tiPRL-R transcript is also visualized in the skin. Previous studies showed the induction of the tegumentary thickness and the mucocyte density by PRL in tilapia Oreochromis mossambicus (Wendelaar Bonga \& Weiss 1981, Flik et al. 1994). Thus, PRL would directly modulate both differentiation and development of the tilapia epidermis. In both testes and ovaries from Oreochromis niloticus undergoing gametogenesis, a unique $3 \cdot 2 \mathrm{~kb}$ tiPRL-R transcript population is also observed. These findings are in agreement with the in vitro stimulatory effects of tiPRL on testis testosterone production previously described in Oreochromis mossambicus (Rubin \& Specker 1992) and underline a direct regulation of both male and female gonadal functions by PRL in tilapia. Moreover, recent studies of plasma PRL levels during the course of a female reproductive cycle by Tacon et al. (2000) indicated that PRL might be involved in the regulation of vitellogenesis and a possible implication of one of the two PRL isoforms in the control

FIGURE 3. In situ hybridization of the prolactin receptor (PRL-R) in the tissues collected from fresh water-reared tilapia. Sense (Fig. 3B and F) and antisense (Fig. 3A, C, E and G) RNA probes have been derived from the extracellular domain of the tiPRL-R and synthesized using fluorescein-11-dUTP. Intestine sections were counterstained with methyl green. In the gill (Fig. 3A, B and C), the tilapia PRL-R expression was visualized within the chloride cells (CC) localized in the epithelium of the primary lamella (PL). Mucous cells (Mu) were unlabeled (Fig. 3A and B: scale bar $=50 \mu \mathrm{m} ; 3 \mathrm{C}$ : scale bar $=10 \mu \mathrm{m}$ ). Branchial chloride cells and mucous cells were respectively identified with an anti-Na ${ }^{+}, \mathrm{K}^{+}$-ATPase $\alpha$ subunit antibody and PAS staining (Fig. $3 \mathrm{D}$ : scale bar $=10 \mu \mathrm{m}$ ). In the intestine, the enterocytes $(\mathrm{E})$, mucous cells $(\mathrm{Mu})$ and chorion $(\mathrm{Ch})$ of the intestinal epithelium displayed a specific expression of the tilapia PRL-R, whereas the muscularis layer (ML) was weakly labeled (Fig. 3E and F: scale bar $=50 \mu \mathrm{m} ; 3 \mathrm{G}$ : scale bar $=10 \mu \mathrm{m}$ ). No signal was detectable in the muscle (Fig. $3 \mathrm{H}$ : scale bar $=50 \mu \mathrm{m})$. 
of maternal behavior was also suggested. Identification of the PRL target cells in both ovary and testis, as well as the time course quantification of tiPRL-R expression during maturation, might yield information concerning PRL functions in fish reproduction, especially during the female sexual cycle, for which the reproductive effects of PRL are unclear (Weber \& Grau 1995, Tacon et al. 2000).

PRL actions in the central nervous system of mammals and birds are well established (Horseman \& Buntin 1995, Ben-Jonathan et al. 1996). In our study, the presence of a $3.2 \mathrm{~kb}$ transcript detected in the male tilapia brain suggests direct effects of PRL in the fish central nervous system. This result argues in favor of the involvement of PRL in reproductive behavior regulation, as suggested by an initial work on cichlids (Blüm \& Fiedler 1965). A mapping of brain regions expressing the tiPRL-R in relation to various physiological situations would give new insights of PRL roles in the central nervous system of tilapia.

PRL is known to influence the mammalian immune system and many studies have demonstrated PRL-R expression in hematopoietic organs, as well as in immune cells (Weigent 1996). In fish, a recent publication has identified a relationship between PRL and immunity, by reporting the in vitro modulation of macrophage activity by salmon PRL in the rainbow trout (Sakai et al. 1997). Moreover, binding sites for rainbow trout PRL have been detected on circulating lymphocytes isolated from this species (O Jolois, $\mathrm{F}$ RentierDelrue, P Prunet \& B Rentier, unpublished data). Together with these findings, the expression of the tiPRL-R mRNA in two major hematopoietic organs, the spleen and the head kidney, as well as the circulating lymphocytes, strongly supports a direct relationship between PRL and immunoregulation in fish, as previously described in the higher vertebrates. Another interesting point underlined by our data is the lower signal intensity exhibited by the spleen and lymphocytes when compared with the head kidney. This probably suggests a higher level of tiPRL-R mRNA expression in the hematopoietic cell populations localized in the head kidney. However, a recent report has highlighted an enhancing effect of both tiPRLs on plasma cortisol levels in Oreochromis mossambicus (Flik et al. 1994). Therefore, since corticosteroid synthesis is performed by the interrenal cells of the head kidney (Balm et al. 1989), it could be that tiPRLs directly affect the activity of the corticosteroid secreting cells, as recently demonstrated in human adrenal glands (Glasow et al. 1996). Cellular localization of tiPRL-R transcripts in the head kidney would confirm such a hypothesis.
In addition to the tissue distribution of the PRL-R in tilapia, these Northern blot analyses were used to study the pattern of the tiPRL-R transcriptional expression. In vertebrates, whilst the long form of PRL-R has been reported in all the species studied so far, including birds and fish, other PRL-R forms exhibiting short cytoplasmic domains have only been identified in mammals (Anthony et al. 1995, Hu et al. 1998, Jabbour et al. 1998). Each PRL-R form is encoded by one or several specific transcripts, and a cDNA probe spanning the extracellular domain allows the detection of all the transcripts encoding both long and short forms by Northern blot analysis (Kelly et al. 1991, Cassy et al. 1998, Jabbour et al. 1998). By using either the $0.9 \mathrm{~kb}$ cDNA probe encompassing the extracellular domain of the tiPRL-R and a part of the 5 non-coding region, or a $0.5 \mathrm{~kb}$ cDNA probe (BamH1-Pst1 fragment; Sandra et al. 1995) encoding the distal portion of the tiPRL-R intracellular domain (O Sandra \& $\mathrm{P}$ Prunet, unpublished data), we identified one single $3.2 \mathrm{~kb}$ tiPRL-R transcript whatever the tissue or the salinity condition tested. Thereby, the expression of this unique tiPRL-R RNA is in contrast to the complex pattern of transcriptional expression reported for mammalian PRL-R and agrees with our earlier binding studies suggesting a unique tiPRL-R for both tiPRLs (Auperin et al. 1994b). Nevertheless, since the two tiPRL forms have been reported to exert different biological actions (Kitta et al. 1993, Auperin et al. 1994a, Shepherd et al. 1997, Sohm et al. 1998), the existence of a second PRL-R form in tilapia cannot be totally ruled out.

Using a non-radioactive in situ hybridization procedure, the cellular localization of the tiPRL-R was examined in the gill and the posterior intestine of tilapia reared in FW. This study demonstrated the presence of the tiPRL-R expression within the gill chloride cells and the intestine mucosal layer, including the enterocytes. The specificity of such localization was assessed using an anti- $\mathrm{Na}^{+}, \mathrm{K}^{+}$ATPase antibody which specifically recognizes chloride cells. In a preliminary experiment, some in situ hybridization signal was also observed in mucous cells, but further experiments clearly established that this signal was neither specific nor reproducible. Thus, the regulation of the tiPRL-R expression in gill mucous cells seems different from that in intestinal mucous cells where a specific signal has been clearly observed. Expression of PRL-R in chloride cells is consistent with the previous physiological studies carried out in tilapia. Administration of ovine PRL to sea water (SW)-adapted tilapias Oreochromis mossambicus has been shown to inhibit the chloride secretion and to reduce the size 
of these chloride cells (Foskett et al. 1982, Herndon et al. 1991). Likewise, in Oreochromis niloticus adapted to BW, tiPRL-I treatment brings about a size reduction of the voluminous $\alpha$-chloride cells and the appearance of smaller chloride cells, whose features are those of $\beta$-chloride cells which are specifically present in FW gill epithelium (Pisam et al. 1993). In tilapia intestine, salt and water absorption has been shown to be stimulated by PRL injection in SW-adapted tilapias (Mainoya 1982). Therefore, the expression of the tiPRL-R in the branchial chloride cells and the intestine epithelial cells confirms the direct regulation by PRL of ionic and water exchanges in tilapia.

In summary, our data illustrate the wide distribution of the PRL-R in tilapia which has been previously described in the higher vertebrates and suggest phylogenic conservation of PRL physiological functions throughout the vertebrates. Moreover, the identification of target tissues and cells for PRL indicates a direct control exerted by this hormone on several biological processes, especially osmoregulation. A more complete understanding of the osmoregulatory role of PRL in tilapia will come from further analysis of PRL-R expression in gill, kidney and gut tissues after salinity changes.

\section{ACKNOWLEDGEMENTS}

We are grateful to Professor Y Valotaire for the gift of the rainbow trout $\beta$-actin cDNA and to Frederic Borel for fish management. The authors are grateful to Professor P Kelly for helpful discussions. We also thank Dr B Shepherd for critical reading of the manuscript and Dr N Bury for correcting the English.

\section{REFERENCES}

Anthony RV, Smith GW, Duong A, Pratt SL \& Smith MF 1995 Two forms of the prolactin receptor messenger ribonucleic acids are present in ovine fetal liver and adult ovary. Endocrine 3 291-295.

Auperin B, Rentier-Delrue F, Martial JA \& Prunet P $1994 a$ Evidence that the two (Oreochromis niloticus) prolactins have different osmoregulatory functions during adaptation to a hyperosmotic environment. Fournal of Molecular Endocrinology 12 13-24.

Auperin B, Rentier-Delrue F, Martial JA \& Prunet P $1994 b$ Characterization of a single prolactin (PRL) receptor in tilapia (Oreochromis niloticus) which binds both tiPRL $\mathrm{I}_{\mathrm{I}}$ and tiPRL ${ }_{\mathrm{II}}$. Fournal of Molecular Endocrinology 13 241-251.

Aviv H \& Leder P 1972 Purification of biologically active globin messenger RNA by chromatography on oligothymidylic acid-cellulose. Proceedings of the National Academy of Sciences of the USA 69 1408-1412.
Balm PHM, Lambert JDG \& Wendelaar Bonga SE 1989 Corticosteroid biosynthesis in the interrenal cells of the teleost fish, Oreochromis mossambicus. General and Comparative Endocrinology 76 53-62.

Ben-Jonathan N, Mershon JL, Allen DL \& Steinmetz RW 1996 Extrapituitary prolactin: distribution, regulation, functions, and clinical aspects. Endocrine Reviews $\mathbf{1 7}$ 629-669.

Bole-Feysot C, Goffin V, Edery M, Binart N \& Kelly PA 1998 Prolactin (PRL) and its receptor: actions, signal transduction pathways and phenotypes observed in PRL receptor knockout mice. Endocrine Reviews 19 225-268.

Blüm V \& Fiedler K 1965 Hormonal control of reproductive behavior in some Cichlid fish. General and Comparative Endocrinology 5 186-196.

Cassy S, Charlier M, Belair L, Guillomot M, Charron G, Bloch B \& Djiane J 1998 Developmental expression and localization of the prolactin receptor (PRL-R) gene in the ewe mammary gland during pregnancy and lactation: estimation of the ratio of the two forms of PRL-R messenger ribonucleic acid. Biology of Reproduction 58 1290-1296.

Chomczynski P \& Sacchi N 1987 Simple step method of RNA isolation by acid guanidinium thiocyanate-phenolchloroform extraction. Analytical Biochemistry 162 156-159.

Church GM \& Gilbert W 1984 Genomic sequencing. Proceedings of the National Academy of Sciences of the USA 81 1991-1995.

Dharmamba M \& Maetz J 1972 Effects of hypophysectomy and prolactin on the sodium balance of Tilapia mossambica in fresh water. General and Comparative Endocrinology 19 175-183.

Dharmamba M \& Maetz J 1976 Branchial sodium exchange in sea water-adapted Tilapia mossambica: effects of prolactin and hypophysectomy. Fournal of Endocrinology 70 293-299.

Dharmamba M, Handin RI, Nandi J \& Bern HA 1967 Effect of prolactin on freshwater survival and on plasma osmotic pressure of hypophysectomized Tilapia mossambica. General and Comparative Endocrinology 9 295-303.

Flik G, Rentier-Delrue F \& Wendelaar Bonga SE 1994 Calcitropic effects of recombinant prolactins in Oreochromis mossambicus. American Fournal of Physiology 266 R1302-R1308.

Foskett JK, Machen TE \& Bern HA 1982 Chloride secretion and conductance of teleost opercular membrane: effects of prolactin. American Fournal of Physiology 242 R380-R389.

Glasow A, Breidert M, Haidin A, Andegerg U, Kelly PA \& Bornstein SR 1996 Functional aspects of the effect of prolactin (PRL) on adrenal steroidogenesis and distribution of the PRL receptor in the human adrenal gland. Fournal of Clinical Endocrinology and Metabolism 81 3103-3111.

Herndon TM, McCormick SD \& Bern HA 1991 Effects of prolactin on chloride cells in opercular membrane of seawater-adapted tilapia. General and Comparative Endocrinology 83 283-289.

Hirano T 1986 The spectrum of prolactin action in teleosts. In Comparative Endocrinology: Developments and Directions, pp 53-74. Ed CR Ralph. New-York: Alan Liss.

Horseman ND \& Buntin JD 1995 Regulation of pigeon cropmilk secretion and parental behaviors by prolactin. Annual Review of Nutrition 15 213-238.

Hu ZZ, Zhuang L \& Dufau ML 1998 Prolactin receptor gene diversity: structure and regulation. Trends in Endocrinology and Metabolism 9 1143-1146.

Jabbour HN, Clarke LA, Bramley T, Postel-Vinay MC, Kelly PA \& Edery M 1998 Alternative splicing of the prolactin receptor gene generates a $1.7 \mathrm{~kb}$ RNA transcript that is linked to prolactin function in the red deer testis. Fournal of Molecular Endocrinology 21 51-59. 
Kelly PA, Djiane J, Postel-Vinay MC \& Edery M 1991 The growth hormone/prolactin receptor family. Endocrine Reviews 12 235-251.

Kitta K, Makino M, Oshima N \& Bern HA 1993 Effects of prolactins on the chromatophores of the tilapia, Oreochromis niloticus. General and Comparative Endocrinology 92 355-365.

Mainoya JR 1982 Water and $\mathrm{NaCl}$ absorption by the intestine of tilapia Sarotherodon mossambicus adapted to fresh water or seawater and the possible role of prolactin and cortisol. Fournal of Comparative Physiology 146 1-8.

Pakdel F, Le Guellec C, Vaillant C, Le Roux MG \& Valotaire Y 1989 Identification and estrogen induction of two estrogen receptors (ER) messenger ribonucleic acids in the rainbow trout liver: sequence homology with other ERs. Molecular Endocrinology 3 44-51.

Pisam M, Auperin A, Prunet P, Rentier-Delrue F, Martial J \& Rambourg A 1993 Effects of prolactin on $\alpha$ and $\beta$ chloride cells in the gill epithelium of the saltwater adapted tilapia Oreochromis niloticus. Anatomical Record 235 275-284.

Prunet P \& Auperin B 1994 Prolactin receptors. In Fish Physiology, vol XIII, pp 367-391. Eds NM Sherwood \& CL Hew. New-York: Academic Press.

Rentier-Delrue F, Swennen D, Prunet P, Lion M \& Martial JA 1989 Tilapia prolactin: molecular cloning of two cDNAs and expression in Escherichia coli. DNA 8 261-270.

Rubin DA \& Specker JL 1992 In vitro effects of homologous prolactins on testosterone production by testes of tilapia (Oreochromis mossambicus). General and Comparative Endocrinology 87 189-196.

Sakai M, Kobayashi M \& Kawauchi H 1996 In vitro activation of fish phagocytic cells by $\mathrm{GH}$, prolactin and somatolactin. Fournal of Endocrinology 151 113-118.

Sandra O, Sohm F, De Luze A, Prunet P, Edery M \& Kelly PA 1995 Expression cloning of a cDNA encoding a fish prolactin receptor. Proceedings of the National Academy of Sciences of the USA 92 6037-6041.

Shepherd BS, Sakamoto T, Nishioka RS, Richman NH, Mori I, Madsen SS, Chen TT, Hirano T, Bern HA \& Grau EG 1997 Somatotropic actions of the homologous growth hormone and prolactin in the euryhaline teleost, the tilapia,
Oreochromis mossambicus. Proceedings of the National Academy of Sciences of the USA 94 2068-2072.

Shiraishi K, Matsuda M, Mori T \& Hirano T 1999 Changes in expression of prolactin- and cortisol-receptor genes during early-life stages of euryhaline tilapia (Oreochromis mossambicus) in fresh water and seawater. Zoological Science 16 139-146.

Sohm F, Pezet A, Sandra O, Prunet P, de Luze A \& Edery M 1998 Activation of gene transcription by tilapia prolactin variants tiPRL188 and tiPRL177. FEBS letters 438 119-123.

Tacon P, Baroiller JF, Le Bail PY, Prunet P \& Jalabert B 2000 Effects of eggs deprivation on the evolution of sex steroids, gonadotrophin, prolactin and growth hormone during the reproductive cycle of the mouthbrooding cichlid fish Oroechromis niloticus. General and Comparative Endocrinology $11754-65$

Weber GM \& Grau EG 1995 Changes in serum and pituitary levels of prolactin and growth hormone with reproduction and fasting in the tilapia Oreochromis mossambicus. In Proceedings of the Fifth Symposium on the Reproductive Physiology of Fish (abstract). Eds FW Goetz \& P Thomas. Austin: Fish Symposium 95.

Weigent DA 1996 Immunoregulatory properties of growth hormone and prolactin. Pharmacology and Therapeutics 69 237-257.

Wendelaar Bonga SE \& Meis S 1981 Effects of external osmolality, calcium and prolactin on growth and differentiation of the epidermal cells of the cichlid teleost Sarotherodon mossambicus. Cell and Tissue Research 221 109-123.

Wendelaar Bonga SE \& Van der Meij JCA 1981 Effect of ambient osmolarity and calcium on prolactin cell activity and osmotic water permeability of the gills in the teleost Sarotherodon mossambicus. General and Comparative Endocrinology 43 432-442.

Yamaguchi K, Specker JL, King DS, Yokoo Y, Nishioka RS, Hirano T \& Bern HA 1988 Complete amino acid sequence of a pair of fish (Tilapia) prolactins, $\mathrm{tPRL}_{177}$ and $\mathrm{tPRL}_{188}$. Fournal of Biological Chemistry 263 9113-9121.

RECEIVED 1 June 1999 